\title{
Literary Learning as Character Enlightenment of Students
}

\author{
Abdul Hasim ${ }^{1}$, Agus Hamdani ${ }^{2}$, Arief Loekman $^{3}$, Iin Indriyani ${ }^{4}$ \\ \{abdulhasim@institutpendidikan.ac.id\} \\ Institut Pendidikan Indonesia Pendidikan (IPI) Garut
}

\begin{abstract}
The substance of science is a bright light for human life. Students who are studying or studying need to get enlightenment from the subject matter they are learning. Substantive learning of literature must be able to deliver students to the discovery of noble character values. For example, from just proverb material, students are invited to explore and discover character values. Furthermore, the character values are digested and internalized in the students to then be implemented or manifested in walking through life. In fact, literary learning is so wide ranging from fairy tales, proverbs, poetry, poetry, fiction prose, to drama with estuary goals so that students actively develop their potential to have religious spiritual power, selfcontrol, personality, intelligence, noble character, and skills what he needed, for society, nation, and country.
\end{abstract}

Key words: literary learning, character enlightenment, students.

\section{Introduction}

Character and national culture education is being and continues to be developed in various subjects, not except Indonesian language subjects in schools. Thus, all subjects including Indonesian must contribute positively in building the character of students.

This is in line with government policy through Presidential Decree Number 87 of 2017 concerning strengthening character education. Previously, the same announcement was made on May 2, 2010 by President Susilo Bambang Yodoyono about character education and national cultural values.

If traced back, even in the colonial era character education was included in the education curriculum for prospective teacher teachers (elementary school, now). In the late period of Dutch colonialism in Indonesia (1940-1942) there were many types of teacher schools, each of which had different characteristics.

For example, in 1941 there was a Village School teacher education course (Cursus Opleiding voor Volks Onderwyzer / OVVO) with two years of education. OVVO students are prepared to master the subjects of counting, writing, reading, drawing, singing, and playing (sports, gestures, how to teach), and character / morals to be taught to Village School students.

In addition, there is Normalschool (NS). This school accepts students from the People's School (SR) 5-6 years. The duration of study is four years, the graduates become Village School teachers. SN uses introduction to regional languages as the language of instruction and is specifically for male students. The NS curriculum includes: Malay, Sundanese / Javanese, Sundanese / Javanese writing, Educating Science, Teaching Science, Life Sciences, Counting, Sound Art, Sports, Arabic Writing, Drawing, Handwork, Agriculture, Plant Sciences, Dutch (elementary), Moral, Economy, and Writing. All students live in a dormitory. Students who are accepted in the SN are Vervolgschool graduates who pass the entrance examination. (Supriadi, 2003: 54-55) 
Therefore, the real issue of character education is not a new "item". That has been a concern for a long time in the world of education. In fact, the character load that is packaged in the subjects of Character, Moral, and Ethics already exists in even the colonial curriculum. Now, the real problem is how character values are present in every subject, including literary lessons, to be internalized in students so that they become individuals who have noble, moral or noble character. Thus, the achievement of noble character for students is a necessity in every learning because it is contained in the national education goals.

The purpose of writing this paper is to present Indonesian language learning, especially literary material in order to provide enlightenment to students through character values contained in kessatraan material to build character or personality of students.

\section{Method}

Literary learning in Indonesian language subjects in schools must be really used to build character or character of students. Considering, the material of literature is loaded with the contents of the values forming the character of the students.

In order to find a moral message on literary learning material appropriate analysis methods are needed. Of the many methods of reading the literature to find the true meaning of hermeneutic reading. Hermeneutics is one type of philosophy that learns about the interpretation of meaning. Thus, a literary text is interpreted until the values contained in it are found.

The moral message and values as the essence of literature are not easily found in literary material. This must be explored with a systematic reading approach, because it is not enough with heuristic reading. Hermeneutic reading is reading that involves interpretation.

\section{Result and Discussion}

Literary learning is so wide ranging from fairy tales, proverbs, poetry, poetry, fiction prose, to drama with estuary goals so that students actively develop their potential to have religious spiritual power, self-control, personality, intelligence, noble character, and the necessary skills himself, for society, nation, and country.

Literary learning actually leads to the discovery of moral messages in which values are very useful. Moral and values messages are certainly not easy to find, interpretation is needed so that moral and character values are obtained. Thus, in the semiotic view, language is a sign system, and as a sign of language represents something else called meaning. Language as a sign system in literary texts does not only refer to the first order semiotic system, but rather refers to the second level semiotic system. This is in line with the process of reading literary texts that are heuristic and hermeneutic.

For example, from just a proverb, if explored there will be found values of very noble characters. Example: "Water pouring from the roof of the fall into the drainage too". The meaning of this proverb is, 'the characteristics of parents usually decrease to their children'. Is an Indonesian language teacher enough to deliver proverb material to interpret each proverb? Of course not, teachers and students must explore in order to find the true and substantive values of the teaching material conveyed in learning. The meaning of the proverbs leads us (teachers and students) to the discovery that the example of parents is something very important because it has an impact or will be imitated by their children. Exemplary character values must be 
embedded in students. Given the importance of exemplary, students must understand and imitate exemplary behavior.

Just to clarify the eloquence of character values in literary material such as proverbs, one more example is proverb, "Kalah becomes ash, wins become charcoal". That is, 'the result of a fight, win or lose will both get a loss'. The interpretation that can be extracted from the proverb is that there is no advantage for people fighting, fighting, fighting, and fighting with other people or other parties because there is no party to win, even Winning will suffer losses, let alone lose. Therefore, if students understand the moral message of the proverb, awareness of themselves will be present, the attitude to always want to be friends, love each other, avoid hostility because it is believed that they will not be lucky.

Such a way of learning, it is important to deliver students to learning activities that are both challenging and enjoyable. Give stimulus students in the form of questions to find a number of proverbs, interpret them, and find moral messages or character values from that proverb.

Of course other literary material such as stories (short stories or novels) provide more opportunities to find moral messages or character values that are high. For example, Indonesian language teachers teach literary material about fiction prose. The fictional prose used as teaching material entitled "Slilit of the Kiai" by Emha Ainun Nadjib.

It is said that there was a kiyai who was in the grave. This is known through the dream of a santri. Santrinya met with Pak Kiai in a dream, which turned out Kiai was held at the door of the heaven. In his dream, Pak Kiai said, "My sins have been forgiven by God, except for one. I did not have the permission of the house owner to take a little of his bamboo to make it a toothpick. That makes me very troubled in the graveyard"

The moral message in the "Slilit of the Kiai" is very profound. How slilit that is underestimated has troubled a Kiai to reach heaven. Therefore, we should not take the rights of others as little as possible. Thus, based on the mandate of the story, the character values that can be found in the story are honest and responsible. Furthermore, it is hoped that these values can be applied in daily life (Hasim, in the 2016 National Seminar Proceedings: 5000).

Through a hermeneutic reading of moral messages and character values will be explored. For example, how do we understand and interpret the story of "Slilit of the Kiai" by Emha Ainun Nadjib which contains a very high moral message, full of meaning, and has noble character values.

Slilit-shaped objects with a very small size also become extraordinary disasters if it is not ours. Use moreover to eat the rights of others as little as anything that is prohibited in religious teachings. That is, honesty is something very valuable. This understanding will bring awareness so that it embodies a character embraced by students. Let alone do corruption with the number of billions or even trillions, objects that are considered "worthless" even if it is not our right we should refrain from taking it. This is the character and mental attitude which includes noble character.

Our concern in witnessing the phenomenon of life inequality or inequality in this country can actually be found in a literary work. This can be used as literary teaching material to present character values that must be absorbed and internalized by students.

For example, the poem W.S. Rendra is titled "Sajak Ibunda" below. Thief has a mother. Mother's murderers. / Likewise corruptors, facist tyrants, / envelope reporters, and parliamentarians are bought, / they also have a mother // ... Will the child say to his mother: / Mother, I have become a stooge of foreign capital, / who produce goods that do not deal with / destitute the people // ... Mother, now I understand more of your values / You are a monument to my life, / which is not made bland like Monas and / Mini parks. 
The metropolitan ecological expression, opens our eyes that urban conditions are indeed much tougher; that urban society on the one hand is meticulous and efficient, but on the other hand is often destructive, sadistic, and tends to like to boast monuments as if their achievements are unmatched. Indeed, the monument still shows the splendor that is lame with the economic conditions of the majority of the people (Endraswara, 2016: 87-88). Character values that can be found by students in the poem include: realistic, that life in the capital is harder; solidarity, that the balance of life is one reason because of ignorance in the lives of our people, especially in big cities.

Therefore, the task of teachers in literary learning is actually trying to facilitate appreciation of literary works by students (Mustika, in "Literature and Character of Bansgsa Education", 2011: 57). Indeed, when students appreciate literature, novels for example, they will involve cumulative psychological processes, in the form of experiences that each student already has (Azis and Hasim, 2010: 83). With each experience that will be found values that are meaningful to him. Furthermore, it is expected to be able to manifest values that are understood and lived in everyday life.

\section{Conclution}

The above description can be summarized as follows. First, true character education can be found in all subjects and teaching materials, without exception in Indonesian subjects, any teaching material, even though proverbs; whereas, literary teaching materials are very broad. Second, the teacher must be a way to make it easier for students in an effort to present character values in each learning material so that students get enlightenment. Katiga, understanding and appreciation of character values found in literary teaching material by students should be simultaneous with their understanding and experience so that students will be able to manifest these values in their daily lives contextually.

\section{References}

Azies, Furqonul, dan Hasim, Abdul. (2010). Menganalisis Fiksi: Sebuah Pengantar. Bogor: Ghalia Indonesia.

Bardy, L. (1985). Ungkapan dan Peribahasa. Klaten: PT Intan.

Damaianti, Vismaia S.(ed) (2011). Riksa Bahasa:Pendidikan Karakter Bahasa dan Sastra Indonesia. Bandung: Rizqi Press.

Endang, Dede. (ed). (2016). Prosiding Seminar Nasional: Pengembangan Literasi Berbasis Kearifan Lokal Pengukuhan Jatidiri Kebudayaan Bangsa. Cirebon: FKIP Unswagati Press.

Endraswara, Suwardi. (2016). Metodologi Penelitian: Ekologi Sastra Konsep, Langkah, dan Penerapan. Yogyakarta: FBS Universitas Negeri Yogyakarta.

Harras, Kholid A. (ed). (2011). Pendidikan Sastra dan Karakter Bangsa. Bandung: Jurdiksastrasia FPBS UPI

Peraturan Presiden Republik Indonesia, Nomor 87 Tahun 2017. Penguatan Pendidikan Karakter. 
Supriadi, Dedi. (2003). Guru di Indonesia: Pendidikan, Pelatihan dan Perjuangan Sejak Zaman Kolonial Hingga Era Reformasi. Jakarta: PT Geranusa Jaya.

Zaimar, Okke Kusuma Sumantri. (2014). Semiotika dalam Analisis Karya Sastra. Depok Indonesia: Komodo Books. 